BIBLIOTIKA : Jurnal Kajian Perpustakaan dan Informasi

Volume 3 Nomor 1, 2019

Journal homepage $:$ http://journal2.um.ac.id/index.php/bibliotika

\title{
PUBLISHING INDUSTRY SEBAGAI PENDUKUNG EKONOMI KREATIF (EKRAF) BAGI PUSTAKAWAN DI ERA DIGITAL
}

\author{
Siti Fatmawati \\ Universitas Negeri Malang
}

\begin{tabular}{|c|c|}
\hline $\begin{array}{l}\text { A R T I C L E } \\
\text { I N F O }\end{array}$ & A B S T RAC T \\
\hline $\begin{array}{l}\text { Article history: } \\
\text { Received: May } 2019 \\
\text { Accepted: } 23 \text { May } 2019 \\
\text { Published: } 31 \text { May } 2019 \\
\text { Keyword: } \\
\text { Kewirausahaan, penerbitan } \\
\text { mandiri, pustakawan, } \\
\text { ekonomi kreatif }\end{array}$ & $\begin{array}{l}\text { Artikel ini membahas tentang peluang bisnis penerbitan mandiri } \\
\text { yang dapat dilakukan oleh pustakawan. Pada era digital saat ini } \\
\text { mempermudah semua aktifitas/kegiatan ekonomi salah satunya } \\
\text { dalam ekonomi kreatif. Industri penerbitan sendiri di Indonesia } \\
\text { sangatlah berkembang dan mendukung tumbuhnya industri } \\
\text { ekonomi kreatif. Artikel ini menggunakan metode studi literatur } \\
\text { dengan pendekatan kualitatif. Tujuan ditulisnya artikel ini adalah } \\
\text { untuk memotivasi pustakawan agar mau berwirausaha khususnya } \\
\text { dalam bisnis penerbitan, dan mendorong mereka agar mampu } \\
\text { melihat peluang yang ada. Sehingga mendorong dan mendukung } \\
\text { pertumbuhan industri kreatif di Indonesia. }\end{array}$ \\
\hline
\end{tabular}

Pada era digital saat ini, industri penerbitan tidak hanya berisi konten tercetak seperti buku. Akan tetapi telah muncul banyak media digital seperti ebook, media sosial, maupun blog. Industri Penerbitan di Indonesia sendiri masih terbukti mampu bertahan di era digital saat ini. hal ini terlihat pada tahun 2016 industri ini mampu memberikan kontribusi yang cukup signifikan bagi perkembangan ekonomi kreatif di Indonesia yakni dengan PDB sebesar 6.32\%, disertai 3,6 \% Laju pertumbuhan PDB Sub-Sektor Penerbitan (Sabdarini, 2016).

Banyaknya jumlah populasi di Indonesia merupakan salah satu faktor penting bagi terus bertumbuhnya industri penerbitan. Hal tersebut akan lebih baik lagi bila diimbangi dengan minat baca yang tinggi pula di masyarakat. Bebasnya para penulis untuk menuangkan imajinasinya juga menjadi faktor penting disini. Banyak penulis-penulis muda yang berbondong-bondong ingin menertbitkan tulisannya baik di penerbit major maupun secara mandiri (selfpublishing).

Bisnis penerbitan juga dapat menjadi daya saing di kancah ekonomi internasional jika dikelola dengan baik. Hal tersebut tentunya dapat mendorong dan mendukung ekonomi kreatif di era digital saat ini. Mungkin jika dibandingkan dengan negara-negara maju, akan sangat sulit negara kita ini untuk bersaing, akan tetapi jika kita dengan jeli menyasar pada industri ekonomi kreatif, bukan tidak mungkin kita unggul dari negara-negara maju tersebut. Pengertian industri kreatif adalah konsep ekonomi pertama yang berisi tentang bagaimana imajinasi dan kreativitas menentukan apa yang orang-orang ingin lakukan dan hasilkan atau sebuah paradigma ekonomi

\footnotetext{
* Corresponding author.

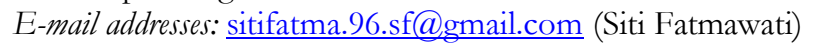

ISSN : 2579-3802 (Online) - BIBLIOTIKA : Jurnal Kajian Perpustakaan dan Informasi is licensed under Creative Commons Attribution-ShareAlike 4.0 International License (http://creativecommons.org/licenses/BY/4.0/). 
baru yang mengandalkan gagasan, ide maupun kreativitas dengan seumber utama manusia sebagai faktor produksi utama kegiatan ekonominya. Sedangkan John Howkins dalam (Sabdarini, 2016) mendefinisikan secara sederhana yaitu ekonomi kreatif yang berhubungan dengan ide dan uang.

Kemudian muncul pula istilah self publishing (penerbitan mandiri) yang menurut (Tim Jago Nulis, 2017) adalah salah satu cara menerbitkan buku oleh penulis tanpa melalui penerbit besar (major publisher) maupun penerbit konvensional. Melalui sistem selfpublishing ini, seorang penulis dapat secara pribadi membukukan naskahnya tanpa memerlukan waktu yang lama. Dalam hal ini penulis berfungsi sebagai penerbit sekaligus karena ia menerbitkan buku atas upaya dan biaya pribadi. Semua hal yang berhubungan dengan penerbitan buku merupakan tanggung jawab dari si penulis. Mulai dari pra produksi seperti penyuntingan, perancangan sampul dan isi buku, pengurusan ISBN, proses produksi atau pencetakan, hingga pemasaran, pendistribusian, konsinyasi di toko buku, promosi, dan sebagainya ditangani sendiri oleh penulis. Akan tetapi dalam praktiknya, belum tentu penulis mengerjakan semuanya benar-benar sendiri, bisa juga dikerjakan atau dibantu oleh pihak lain tentunya dnegan komando si penulis sebagai pihak pemilik naskah dan modal. Kemudian keputusan tentang buku akan dicetak dalam bentu apa, dijual diamana, juga ditentukan olehh penulis dengan estimasi waktu terbit kurang dari tiga bulan.

Perpustakaan sebagai salah satu lembaga non profit yang bertugas memenuhi kebutuhan informasi masyarakat yang dapat ikut andil dengan kemajuan industri penerbitan. Salah satunya dengan menggeluti bidang kewirausahaan penerbitan yang bisa dilakukan oleh pustakawan. Pustakawan sebagai sosok yang dianggap ahli informasi utamanya dalam literasi kepada masyarakat memiliki peluang besar untuk menggeluti bisnis penerbitan ini. Utamanya juga dalam mendalami self publishing. Kerana keseharian pustakawan tak asing dari dunia pengembangan ilmu pengetahuan, pustakawan juga dituntut untuk produktif berkarya. Maka akan sangat menguntungkan jika dapat menerbitkan tulisannya sendiri. Karena selain berjibaku dengan profesinya sebagai pustakawan, mereka juga dapat menjalankan bisnis ini. bisnis penerbitan tidak harus dilakukan secara langsung (dalam artian harus memiliki fisik/gedung) namun juga bisa secara online (maya). Jasa penerbitan dapat dipromosikan melalui media sosial, blog, maupun media online lain bahkan tanpa modal sekalipun.

\section{METODE}

Metode yang digunakan dalam kajian ini adalah studi literature dengan pendekatan kualitatif. Pendekatan kualitatif diartikan sebagai usaha menggabungkan dan menganalisa data untuk dijadikan suatu konsep baru, merumuskan definisi untuk kontruksi utama, dan menggabungkan semuanya. Bentuk dari data yang diperlukan yakni deskripsi tersirat yang dituangkan dalam bentuk narasi/deskripsi dari suatu tindakan spesifik yang menghubungkan antara ide dengan data (Neuman dalam (Puspita, 2018)). Sedangkan menurut Suharsa Putra dalam (Hakim, 2016) Pendekatan kualitatif merupakan paham positivis perwujudan berpikir deduktif. Pendekatan kualitatif menghasilkan data deskriptif naratif berupa kata-kata tertulis atau lisan dan perilaku orang-orang yang diamati kemudian dijelaskan dalam sudut pandang subjek. Kemudian pengertian studi literatur adalah kegiatan membaca, menelaah dan mendalami bahan pustaka seperti buku, artikel, maupun sumber lainnya yang relevan dengan bahasan (Yulius, 2014).

\section{PEMBAHASAN}

\section{Apa itu Ekonomi Kreatif (Ekraf)?}

Bapak Ekonomi kreatif, John Howkins menjabarkan ekonomi kreatif secara sederhana yaitu "Ekonomi Kreatif berhubungan dengan ide dan uang. Ini adalah jenis ekonomi pertama di mana imajinasi dan kreativitas menentukan apa yang orangorang ingin lakukan dan hasilkan". Ekonomi kreatif dapat pula diartikan sebagai konsep ekonomi yang mengandalkan ide, gagasan maupun kreatifitas dari SDM (sumber daya manusia) sebagai faktor utama dalam menjalankan kegiatan ekonominya. Usur yang paling penting dalam konsep ekonomi kreatif adalah kreativitas dan nilai tambah (adanya peningkatan kualitas produk baik dari segi nilai maupun ekonomi). 
Berikut penjabaran keunggulan ekonomi kreatif dibandingkan ekonomi konvensional menurut (Sabdarini, 2016):

1. meningkatkan standar hidup dan gaji rata-rata: kreativitas menjadi modal utama dimana pelaku ekraf dituntut untuk selalu menghasilkan produk terbaik dan inovasi berkelanjutan;

2. ringan modal: sumberdaya utama ekraf adalah kreativitas yang bersifat orisinil, unik, dan terbaru. Sehingga tidak memerlukan modal besar karena modal utama adalah kreativitas sumber daya manusianya

3. ringan sumberdaya alam: karena sumberdaya utama ekraf adalah talenta setiap individu

4. Higher Value Economy: ekraf mempunyai nilai tambah yang tinggi

5. Low barrier to entry: sektor ekraf tidak memerlukan biaya yang besar maupun sertifikasi tertentu:

6. kolaborasi: ekraf menyatukan berbagai individu dari latar belakang dan bidang yang berbeda-beda

7. Mepromisikan HKI Indonesia: hak kekayaan intelektual atau intelektual property merupakan aset yang sangat berharga penciptanya, budaya, bangsa, dan negara itu sendiri

8. fleksibel: ekraf tidak terpaku pada struktur aturan yang kaku

Pada mulanya ekonomi kreatif di Indonesia sudah terlihat sejak tahun 2007 pada acara Pekan Budaya Indonesia. Kemudian pada tahun 2009, pemerintah menerbitkan Intruksi Presiden Nomor 6 Tahun 2009 yang mengatur tentang Pengembangan Ekonomi Kreatif, salah satu pionir landasan hukum yang pertama kali menempatkan Ekraf di panggung perekonomian nasional.

Industri kreatif di Indonesia tercatat melalui pemetaan yang dilakukan oleh Ernst and Young (EY) pada tahun 2015 yang bernilai sebesar 2,3 triliun dolar AS (US\$ 2,3 trillion) atau senilai 30.654 triliun rupiah, dan menyamai 3\% dari PDB total dari seluruh dunia.

Berikut napak tilas Ekonomi Kreatif di Indonesia (dikutip dari (Sabdarini, 2016)):

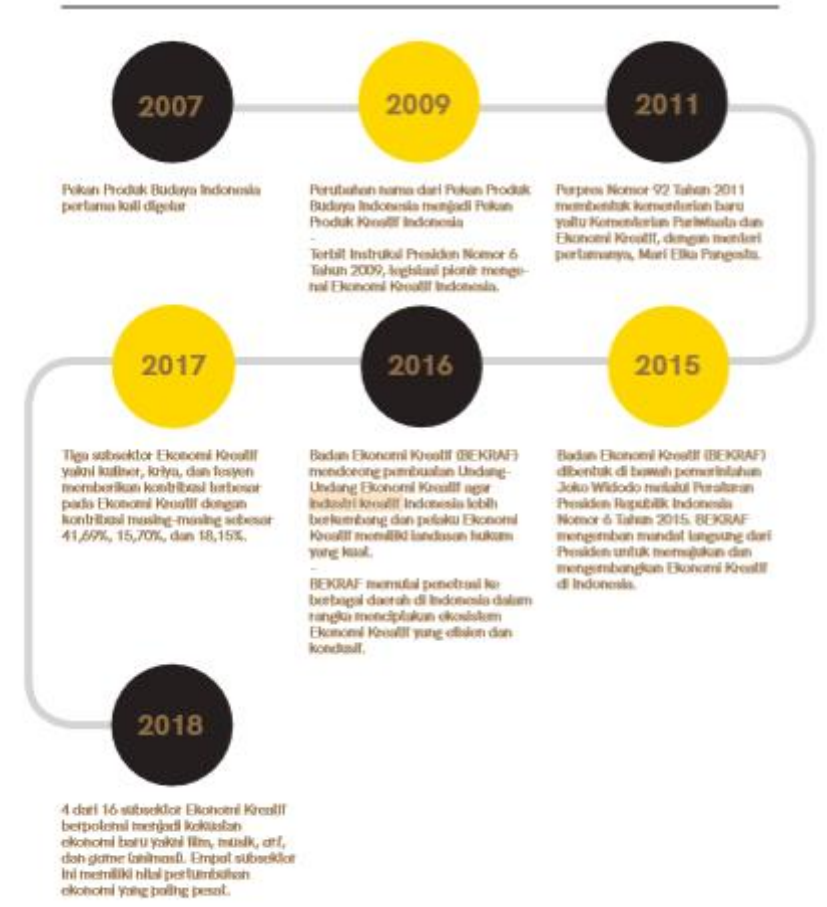

Gambar napak tilas Ekonomi Kreatif di Indonesia

\section{Definisi Penerbitan}

Istilah penerbitan sering disandingkan dan disamakan dengan percetakan, baik oleh orang awam maupun pihak pebisnis. Padahal kedua istilah tersebut mempunyai arti dan makna yang berbeda. 
Penerbitan berasal dari kata "publish" yang mulai dicatat pada awal 1570 dengan pemahaman "the issuing of a written or printed work" atau informasi yang ditulis atau pekerjaan yang dicetak. Pemahaman penerbitan mulai dikembangkan pada 1650 dari bahasa Prancis kuno yang menyebutkan bahwa kata "publish" berasal dari kata "publier' yang mengandung arti "the act of making publicly known". Sedangkan definisi "printing" berasal dari kata "preinte" yang diambil dari Prancis kuno dan bahasa Latin "premere" yang mengandung arti "top press" atau cetak.

Berdasarkan pengertian tersebut, European Commission and Skillset Assesment UK dalam (Rambatan, 2015) mengembangkan definisi sebagai berikut:

1. Penerbitan dapat didefinisikan sebagai proses produksi dan penyebaran informasi, yaitu membuat informasi tersedia untuk publik. Informasi tersebut dapat berupa karya-karya seperti buku, majalah, koran, dan rekaman suara dalam bentuk cetak maupun elektronik. Fokusnya adalah menciptakan konten bagi konsumen.

2. Percetakan adalah proses untuk mereproduksi teks dan gambar, termasuk kegiatan pendukung yang terkait, seperti penjilidan buku, jasa pembuatan piringan, dan pencitraan data. Fokusnya adalah mereproduksi konten dalam bentuk media.

Hassan Pambudi, dalam bukunya, Dasar dan Teknik Penerbitan Buku (1981), mendefinisikan kegiatan menerbitkan sebagai kegiatan yang "mempublikasikan kepada umum, mengetengahkan kepada khalayak ramai, kata dan gambar yang telah diciptakan oleh jiwa-jiwa kreatif, kemudian disunting oleh para penyunting untuk selanjutnya digandakan oleh bagian percetakan. Sedangkan WIPO (2012) mendefinisikan "Publication is the distribution of copies or content to the public.

Berdasarkan definisi-definisi diatas dapat disimpulkan bahwa aktivitas penerbitan lebih bersifat kreasi yang bermuatan konten, sedangkan pada percetakan lebih bersifat produksi dan replikasi hasil karya yang berisikan muatan konten tersebut.

\section{Perkembangan Penerbitan di Indonesia}

Di Indonesia, kita mengenal penerbitan dan percetakan sebagai salah satu subsektor industri kreatif yang perlu dipahami lebih jauh definisi dan ruang lingkupnya sesuai dengan konteks serta perkembangannya saat ini. Beberapa negara maju di Eropa, yaitu Inggris, Jerman, Spanyol, dan Prancis memfokuskan pengembangan ekonomi kreatifnya dalam ruang lingkup penerbitan (publishing), tanpa terlalu menekankan pada "printing" atau industri percetakan.

Model kegiatan penerbitan terus mengalami perkembangan yang jika diperhatikan akan sejalan dengan perkembangan teknologi, yaitu:

1. Penerbitan Tradisional. Penerbitan secara tradisional meliputi kegiatan pemilihan, penyusunan, dan distribusi barang cetakan seperti buku, surat kabar, majalah, dan brosur. Penerbit bertanggung jawab sepenuhnya dalam memutuskan isi, struktur, dan tampilan buku.

2. Penerbitan Elektronik (Digital). Penerbitan elektronik mulai berkembang sehubungan dengan perkembangan Internet. Hal ini memengaruhi keluaran produk dan juga rantai nilai penjualan. Produk yang dulunya berbentuk fisik berubah menjadi bentuk digital. Dalam hal pemasaran, penerbitan model elektronik ini memungkinkan terjadinya interaksi langsung antara pihak penerbit dengan konsumen akhir.

3. Penerbitan Mandiri/Self-publishing. Penerbit memfasilitasi para penulis untuk mempublikasikan karya mereka sendiri dengan pencetakan sesuai permintaan (print on demand). Hal ini membantu para penulis pemula untuk menerbitkan dan memasarkan hasil karyanya tanpa harus mengajukan ke penerbit mayor. Keberadaan self-publishing memberikan efisiensi dalam hal produksi. 
Alur Penerbitan menurut IKAPI (Ikatan Penerbitan Indonesia) dalam (Rambatan, 2015):

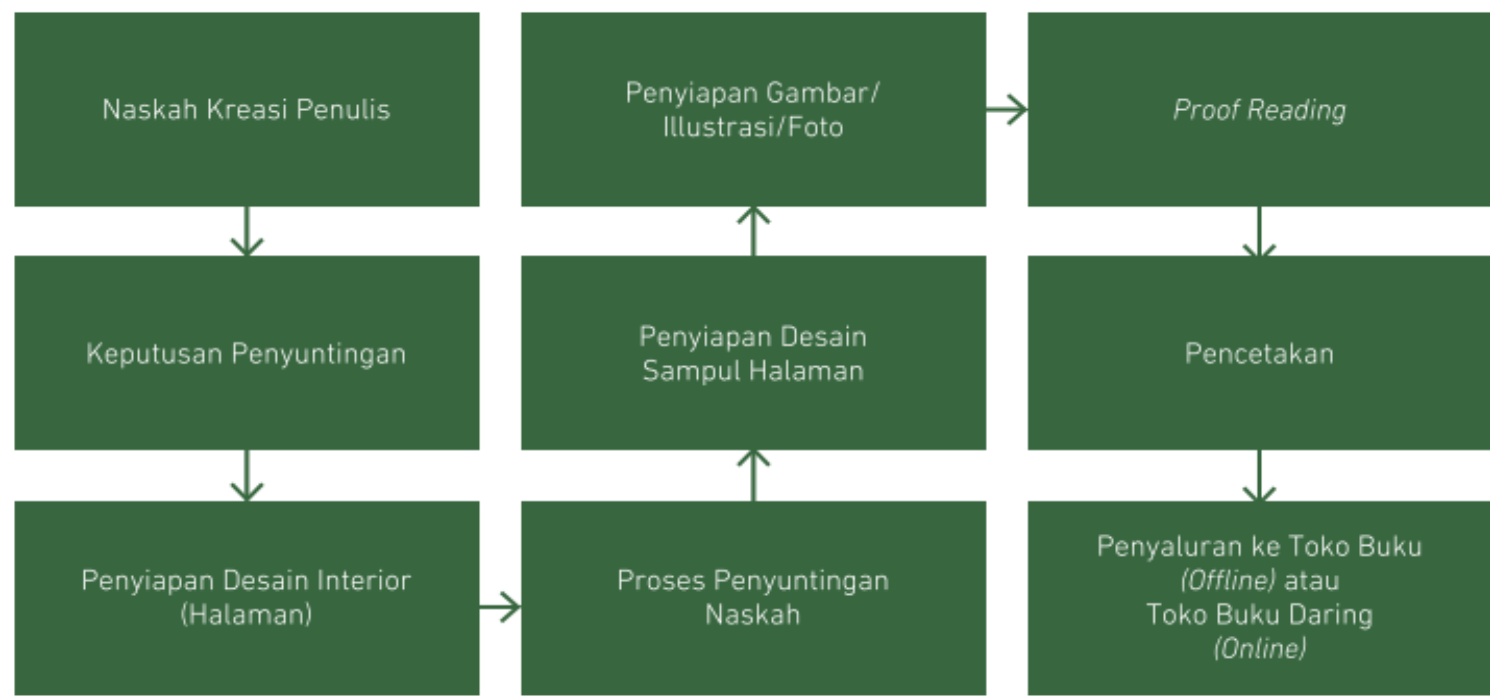

Gambar Alur Penerbitan menurut IKAPI (Ikatan Penerbitan Indonesia)

Dalam definisi penerbitan tersebut, terdapat beberapa kata kunci yang dapat menjelaskan makna penerbitan secara lebih mendalam, yaitu:

1. Konten kreatif adalah informasi yang dikelola melalui proses kreativitas.

2. Keunikan adalah karya kreatif yang memiliki kekhususan atau keistimewaan, berbeda dari yang lain.

3. Diproduksi untuk konsumsi publik adalah karya kreatif yang langsung memenuhi keperluan hidup masyarakat (produk massal).

4. Media adalah segala sesuatu yang dapat menyalurkan informasi dari sumber informasi kepada penerima informasi, meliputi: a. Media Cetak, yaitu media yang terdiri atas lembaran kertas dengan sejumlah kata, gambar, atau foto dengan tata warna dan halaman; b. Media Digital, yaitu media yang terdiri atas data-data digital dan ditampilkan berupa kata-kata, gambar, video, maupun audio di layar; c. Media Daring, yaitu media digital yang dapat diakses secara luas melalui Internet.

5. Nilai adalah manfaat yang diperoleh, meliputi: a. Nilai ekonomi, yaitu nilai yang berhubungan dengan keuntungan secara finansial; b. Nilai sosial, yaitu penghargaan yang diberikan masyarakat terhadap sesuatu yang dianggap baik, luhur, pantas, dan mempunyai daya guna; c. Nilai seni dan budaya, yaitu nilai yang berkaitan dalam pembuatan konten kreatif dengan pengejawantahan estetika dan rasa seni yang di dalamnya mengandung aspek kebudayaan.

\section{Self Publishing}

Self publishing (penerbitan mandiri) adalah salah satu cara menerbitkan buku oleh penulis tanpa melalui penerbit besar (major publisher) maupun penerbit konvensional. Melalui sistem self publishing ini, seorang penulis dapat secara pribadi membukukan naskahnya tanpa memerlukan waktu yang lama. Dalam hal ini penulis berfungsi sebagai penerbit sekaligus karena ia menerbitkan buku atas upaya dan biaya pribadi. Semua hal yang berhubungan dengan penerbitan buku merupakan tanggung jawab dari si penulis. Mulai dari pra produksi seperti penyuntingan, perancangan sampul dan isi buku, pengurusan ISBN, proses produksi atau pencetakan, hingga pemasaran, pendistribusian, konsinyasi di toko buku, promosi, dan sebagainya ditangani sendiri oleh penulis. Akan tetapi dalam praktiknya, belum tentu penulis mengerjakan semuanya benarbenar sendiri, bisa juga dikerjakan atau dibantu oleh pihak lain tentunya dnegan komando si penulis sebagai pihak pemilik naskah dan modal. Kemudian keputusan tentang buku akan dicetak 
dalam bentu apa, dijual diamana, juga ditentukan olehh penulis dengan estimasi waktu terbit kurang dari tiga bulan(Tim Jago Nulis, 2017)

\section{Langkah-langkah self publishing}

Menurut (Tim Jago Nulis, 2017) dalam bukunya, menjelaskan langkah-langkah bangaimana melakukan penerbitan mandiri yang baik, sebagai berikut:

1. Pilih Penerbit buku yang sesuai! Yaitu mengetahui ciri khas setiap penerbitan. Misalnya, penerbit buku A lebih terkonsentrasi kepada buku-buku berbau islami, maka jika ada naskah diluar jenis itu akan secara otomatis ditolak. Maka terlebih dahulu penulis harus jeli dalam mengirim naskah kepada penerbit. Selain itu track record penerbit juga penting untuk diperhatikan

2. Mempertimbangkan jumlah cetak dan lama durasi cetak

3. Menentukan Harga Setelah naskah di cetak

Sebelum menentukan harga perlu perhatikan hal-hal berikut:

1. Survei pasar

2. Menganalisis Pasar Analisa pasar penting dilakukan: yaitu seperti melihat pemetaan dan probabilitas percetakan akan berjalan lancar atau tidak, memilih lokasi yang strategis, pemetaan kinerja yang dijalankan, dan analisa jumlah target pasar yang dituju.

3. Distribusi Buku. Kunci utama kesuksesan dalam menerbitkan sebuah buku adalah pada saat memasarkan buku yang sudah dicetak. Ada banyak cara yang dapat dilakukan: seperti promosi di internet: media sosial, website, blog. Atau dengan sistem distributor yang mana penerbit dapat bekerjasama dengan distributor untuk memasarkan buku yang sudah diterbitkan.

\section{Peluang Bisnis Penerbitan oleh Pustakawan}

Industri penerbitan merupakan salah satu bisnis ekonomi kreatif yang memberikan kontribusi PDB cukup besar yakni sebanyak 6,32\% dan sebanyak 83.496 Jumlah Usaha Yang Bergerak Di Sub-Sektor Penerbitan 2016 (peringkat 4) di Indonesia. Belum pula 464.579 orang Jumlah Tenaga Kerja di Sub-Sektor Penerbitan 2016 (peringkat 4) dengan 83,36\% Persentase Pengusaha di Sub-sektor Penerbitan yang Tidak Berbadan Usaha (5.434.047 usaha). Data didapat berdasarkan buku Opus 2019 dalam (Sabdarini, 2016).

Berdasarkan data diatas, peluang menjajaki bisnis penerbitan ini sangatlah terbuka lebar dan dapat dilakukan oleh siapa saja. Akan tetapi kenapa pustakawan lebih berpeluang besar? Alasannya adalah karena pustakawan dengan profesi dan pekerjaan kesehariaannya lebih familiar dengan hal-hal yang berbau buku dan informasi. Bisa dilihat juga pada tabel alur penerbitan diatas bahwa kegiatan penerbitan lebih banyak berurusan dengan naskah hingga siap didistribusikan. Pekerjaan ini hampir sama dengan proses pengolahan bahan pustaka hingga dilayankan kepada pengguna perpustakaan, dimana pustakawan yang bertindak mengelolanya. Bisnis ini juga dapat menjadi sampingan atau bahkan pendapatan utama karena dalam memulainya pun tanpa memerlukan modal, atau jikapun ada hanyalah sedikit karena keperluan administrasi.

Penawaran jasa penerbitan bagi pustakawan yang baru memulai usaha ini dapat dilakukan di media sosial secara gratis. Kunci dari lancarnya bisnis ini adalah manajemen pengelolaan yang baik, bahkan bila perlu dibuatkan adanya POB (Prosedur Operasional Baku) jika sudah memiliki karyawan agar mekanisme jelas dan saling menguntungkan bagi semua pihak.

\section{SIMPULAN}

Berdasarkan penjelasan diatas dapat disimpulkan bahwa peluang pustakawan sebagai entrepreneur di bidang penerbitan sangatlah terbuka. Apalagi jika melihat pertumbuhan industri penerbitan yang terus mengalami peningkatan dan mendukung pula berkembangnya ekonomi kreatif di Indonesia. Bisnis ini juga relatif mudah dan tidak memerlukan banyak modal bahkan gratis, dan bisa dilakukan di era digital (4.0) melalui media sosial. 


\section{DAFTAR RUJUKAN}

Galuh Ayu Puspita \& Irwansyah. 2018. Pergeseran Budaya Baca dan Perkembangan Industri Penerbitan Buku di Indonesia: Studi Kasus Pembaca E-Book Melalui Aplikasi iPusnas. Diakses melalui (https://r.search.yahoo.com/ ylt=AwrxguqMJ9hcyiQADgP3RQx.; ylu=X3oDMTByc WJpM21vBGNvbG8Dc2czBHBvcwMxBHZ0aWQDBHNIYwNzcg-$\angle \mathrm{RV}=2 / \mathrm{RE}=1557698572 / \mathrm{RO}=10 / \mathrm{RU}=\mathrm{http} \% 3 \mathrm{a} \% 2 \mathrm{f} \% 2$ fjournal2.um.ac.id $\% 2$ findex.ph $\mathrm{p} \% 2$ fbibliotika $\% 2$ farticle $\% 2$ fview $\% 2$ f4164/RK=2/RS=I H8SkpPCNufuGU fSbHvF 68DA-). Pada tanggal 12 Mei 2019. (Jurnal Online)

Hakim, M. A. (2016). Strategi Promosi Perpustakaan di Perpustakaan SMK Negeri 4 Malang. Malang: UM Press.

Jago Nulis, Tim. 2017. Self Publishing! Are You Dare Enough To Be an Author?. Diakses melalui (https://dosen.perbanas.id/wp-content/uploads/2017/04/Ebook-SelfPublishing.pdf). Pada 12 Mei 2019. (e-book)

Rambatan, Galih Bondan. 2015. Rencana Pengembangan Penerbitan Nasional 2015-2019. Diakes melalui

(http://indonesiakreatif.bekraf.go.id/ikpro/wpcontent/uploads/2015/07/Rencana-Pengembangan-Penerbitan-Nasional.pdf). Pada Tanggal 12 Mei 2019. (e-book)

Sabdarini, Rene Tatyana. 2016. Creative Economy Outlook 2019 (Indonesia Version). Diakses melalui (http://www.bekraf.go.id/berita/page/17/opus-creative-economy-outlook2019-indonesia-version). Pada tanggal 10 Mei 2019. (e-book)

Yulius, DYA. 2014. Metodelogi Penelitian. Diakses melalui (http://digilib.unila.ac.id/2100/9/BAB\%20III.pdf). Pada 12 Mei 2019. (jurnal Online) 